\title{
IN TRANSPORT PROCESSES
}

DOI 10.2478/ntpe-2018-0049

\author{
dr inż. Beata Drzewieniecka \\ Maritime University of Szczecin, Poland
}

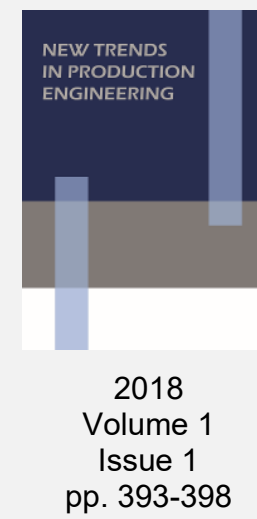

\begin{abstract}
Soybean meal is one of the most popular components of compound feed. The rise of its demand in the world causes a constant interest in this cargo and to conduct research in different directions. This is related to its inherent properties, and to the continuous changes that occur in it. Soybean meal is a solid bulk cargo. Loose soybean meal, apart from larger particles, also contains fine and dusty/ powdery fractions, which create the risk of explosion and environmental pollution. The problem of protecting the environment against dusting of fine fractions of soybean meal is very important in the cargo handling processes. An additional aspect is the destructive effect of powdery fractions during these processes. The results of the research on the degrading effect of fine fractions of soybean meal and its compounds on the means of transshipments were presented. Due to the interaction of esters and other compounds contained in the soybean meal, the research has the implications for the changes in the properties of the rubber elements of the elevator conveyor. The effect of these changes may be the reduced durability of the conveyor belts and the associated risks such as operational failures.
\end{abstract}

Keywords: transport process, soybean meal, conveyor belts, hardness of rubber, elasticity of rubber

\section{INTRODUCTION}

Transport processes include transportation, handling and storage of cargo. During these processes some properties of soybean meal pose a great danger to human life and the environment. There are also many changes with many characteristics that determine the nutritional value and transportability in terms of service quality and technological and transport quality.

Soybean meal is one of the feed ingredients. It is characterized by high nutritional value, due to a high protein content of $44-48 \%$. Its growing demand in the world, as a high protein feed, makes it necessary to test the quality of this raw material.

Dust fumes of this kind of cargo create threats with destructive effects to the transport equipment, the environment and hazards associated with the danger of explosion. According to the IMSBC Code, soybean meal is classified as Hazardous Materials in Class 4.2 as a selfigniting material. In the IMDG Code for the Carriage of Dangerous Goods in Packaging and in the IMSBC Code, which provides transport requirements for bulk transport, soybean meal is included under UN No. 1386 and UN No. 2217, respectively.

In the transport cycle, soybean meal is transported by various specialized means of land and water transport. The transshipment of this cargo is indirectly from water transport to elevators and then to land transport facilities by which it is transported to the storage rooms for feed mills.

The cargo handling of bulk soybean meal may take place by gravity, mechanically and pneumatically. This process is carried out with the use of external transport equipment: pneumatic conveyors, conveyor belts and screw conveyors. Loading of trucks and wagons with soybean meal stored in the elevator is done by means of telescopic tubes and conveyor systems. Internal transport in elevators is carried out by utilization of mechanical conveyor systems - horizontal conveyors (red liners or open conveyors) and vertical or diagonal (buckets) conveyors. 
Unloading of wagons and trucks with tapered bottom or trucks with tilting trailers is carried out at hopper chutes located under the chute openings at the place of landing of soybean meal. Under loading hoppers there are conveyors for internal transport of soybean meal, namely horizontal, diagonal and vertical conveyor systems.

During cargo handling of bulk soybean meal, intense movement of particles and formation of dust occur. Soybean meal consists of different granule fractions. According to the literature of the subject (Drzewieniecka, 2013), dusty fractions account for about $4 \%$ of the mass of the tested cargo. They create explosion hazards, environmental pollution and breakdown of cargo handling equipment (Drzewieniecka, 2010).

There have been carried out researches in connection with the opinion survey of the companies dealing with cargo handling and storage of soybean meal and other oil seeds indicating the accelerated wear of the elements in the transshipment lines during cargo handling of oil seeds.

\section{DESTRUCTIVE ACTION OF DUSTYIPOWDERY SOYBEAN SEED CAKE FRACTIONS}

In the fine fractions of soybean meal, biochemical processes are taking place. The fat content in this cargo can lead to self-heating or even to self-ignition. The factors contributing to these phenomena are: high humidity in the holds and inadequate control, exposure of cargo to wet or dipping, small storage area in the cargo holds, limited ability to control the temperature of the soybean meal and to release the accumulated heat, high shredding of soybean meal and relatively long time of transport.

These factors also influence the formation of unfavorable phenomena which impede transport processes, such as the reduction of flowing causing, among other things, the agglomeration and formation of the agglomerated layers. This leads to a reduction in the flow of transmission pipelines and, as a consequence, difficulties with cargo handling operations. The other negative effects of the cargo compaction are the easier movement and development of microorganisms leading to self-heating. The dusty parts of this cargo also cause the risk of failure due to the destructive impact on the transport equipment.

Transshipment processes are an important element in the transport process. During these processes, destructive impact of the dusty soybean meal fractions has been observed. In the middle of cargo handling operations, dusty cargo fractions are deposited on transport equipment such as conveyor belts which affect the accelerated wear of the conveyor elements.

Soybean meal contains fats in addition to various compounds. In the fine and dusty fractions of this cargo, the content of these compounds is greater. The destructive effect relates in particular to rubber conveyor belts. According to the literature of the subject (Chmiel et al., 2010), the major destructive factor in the process of conveyor belt operation is the erosive impact of the grain stream at the time of its descent into the belt.

The accelerating wear factor was the physico-chemical impact of esters and other compounds contained in the grain on the material of the conveyor belt. From the surface of the grain, these compounds are transferred to the rubber surface of the conveyor belt as a result of adhesion.

The extracted soybean meals are obtained by extracting the fat from the seeds using organic solvents. The residue of fat in the soybean meal is small and ranges from 1 to $2 \%$ (Chachułowa, 1997).

According to author's research the initial fat content of natural soybean meal was $2.67 \%$. The highest initial fat content $4.22 \%$ had the smallest dust particle fraction of $0.075 \mathrm{~mm}$, the fine fraction with particle size $0.075-0.4 \mathrm{~mm}$ had about $3 \%$ of fat content.

Under condition of sea transport conditions and storage of soybean meal in silos, the pressure on the lower parts of the cargo increases, resulting in a partial extrusion of the fatty acid esters onto the surface of the soybean meal particles. This phenomenon can be aggravated in case of cargo caking and self-heating processes, which cause an increase of temperature inside the cargo. 
The pressure of the cargo weight is increased at the moment of the ship's movements at sea and the shifting of the cargo and during soybean seed cake self-sorting phenomena in the silos where the cargo is compacted.

The other negative effects of the cargo compaction are the easier movement and development of microorganisms leading to self-heating. Self-healing is also conducive to self-sorting phenomena. Where there is a mass movement of soybean meal particles, e.g. gravity filling and discharging of the chambers in elevators and during transport of bulk cargo in large load units and means of transport, the larger particles of soybean seed cake accumulate in the middle part of cargo once the smaller particles in the outer masses of the cargo. Due to this phenomenon, the soybean meal particles may be damaged and fatty compounds may be released (Babicz-Zielińska, 2000).

The chemical composition of soybean meal is varied. According to Z. E. Sikorski the fatty acid composition (Sikorski, 2000), can vary widely because it is dependent on many factors, including the soybean grade from which soybean seed cake is produced and soybean growing environment. Soybean oil contains relatively low saturated fatty acids (about 15\%) and is characterized by high levels of unsaturated fatty acids (about 85\%) (Migdał et al., 2001).

From author's research, the content of some fatty acids in soybean meal is as follows: oleic acid $-0.45 \%$, linoleic acid $-1.37 \%$, linolenic acid $-0.19 \%$, palmitic acid $-0.48 \%$ of dry matter.

\section{EXPERIMENTAL PART}

The study was conducted on interaction and influence of soybean oil esters on the properties of the rubber components in conveyor belt. The outer layer of conveyor belt is made of styrene butadiene rubber. The elements of the conveyor belt were placed in a climate chamber at a set temperature of $40^{\circ} \mathrm{C}$ and relative humidity of $70 \%$, a sealed container the ultra thermostat Polyscience 9712 with a programmable controller, for the period of 120 hours. Rubber samples were immersed in soybean oil.

The temperature and humidity parameters correspond to the operating conditions of the conveyor belts. The parameters to be tested were Shore hardness (A scale) - according to PN-C-04238: 1980, and Schobler's stiffness - according to PN-C-04255: 1977.

These methods belong to a group of macroscopic research methods, averaging the changes in properties appearing on the microscope scale.

According to the literature of the subject (Chmiel et al., 2010), during the long-term interaction of the esters contained in soybean oil into the rubber from which the outer belt of the conveyor belt is made, the hardness of the rubber in the Shore's test is significantly reduced. In the case of rapeseed oil the most intense drop of hardness of the rubber was within 60 hours of oil exposure. A similar result was obtained in soybean oil tests. As a result of the research, it was found that the hardness fall of the rubber was the most intense during the first 60 hours of exposure (Figure 1).

The reflection elasticity test consisted of hitting the rubber sample with the swing hammer, lowered from a specified height, and measuring the height of the pendulum's deflection to its height. The measure of the reflection is the quotient of the rebound height and the height of the slope, expressed in percent. In the vertical position of the pendulum, the distance between the anvil and semicircular weights should be equal to the thickness of the sample. The potential energy of the pendulum in its upper position should be $0.5 \mathrm{~J}$, a mass of $250 \mathrm{~g}$, and the speed at the moment of impact on the sample is $2 \mathrm{~m} / \mathrm{s}$. The mechanical energy loss of the pendulum should not be greater than $1.5 \%$.

During prolonged interaction of esters contained in soybean oil on the rubber from which the outer belt of the conveyor belt is made, an increase in the elasticity of the sample was obtained in Schoba's attempt (Figure 2). Similar results were obtained in rapeseed oil (Chmiel et al., 2010). 


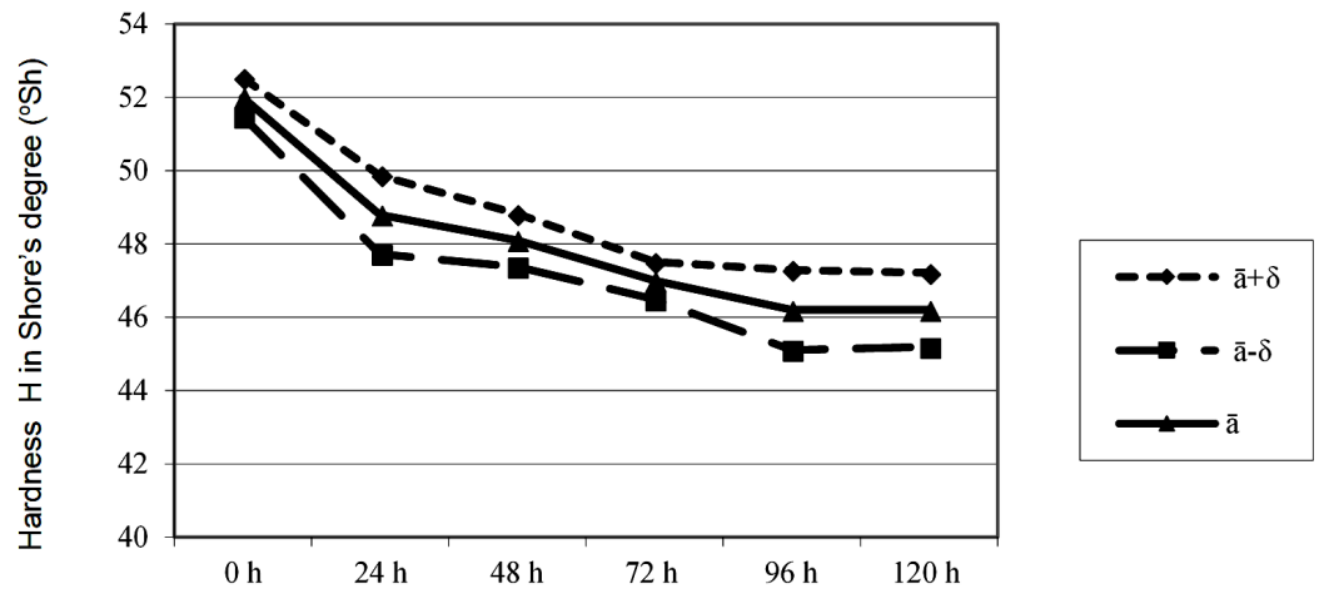

Time $(\mathrm{h})$

Fig. 1. Hardness $H(S h A)$ change of styrene-butadiene rubber after exposure in soybean oil environment. Hardness $\mathrm{H}$ measured in Shore's degree ('Sh). Source: own elaboration.
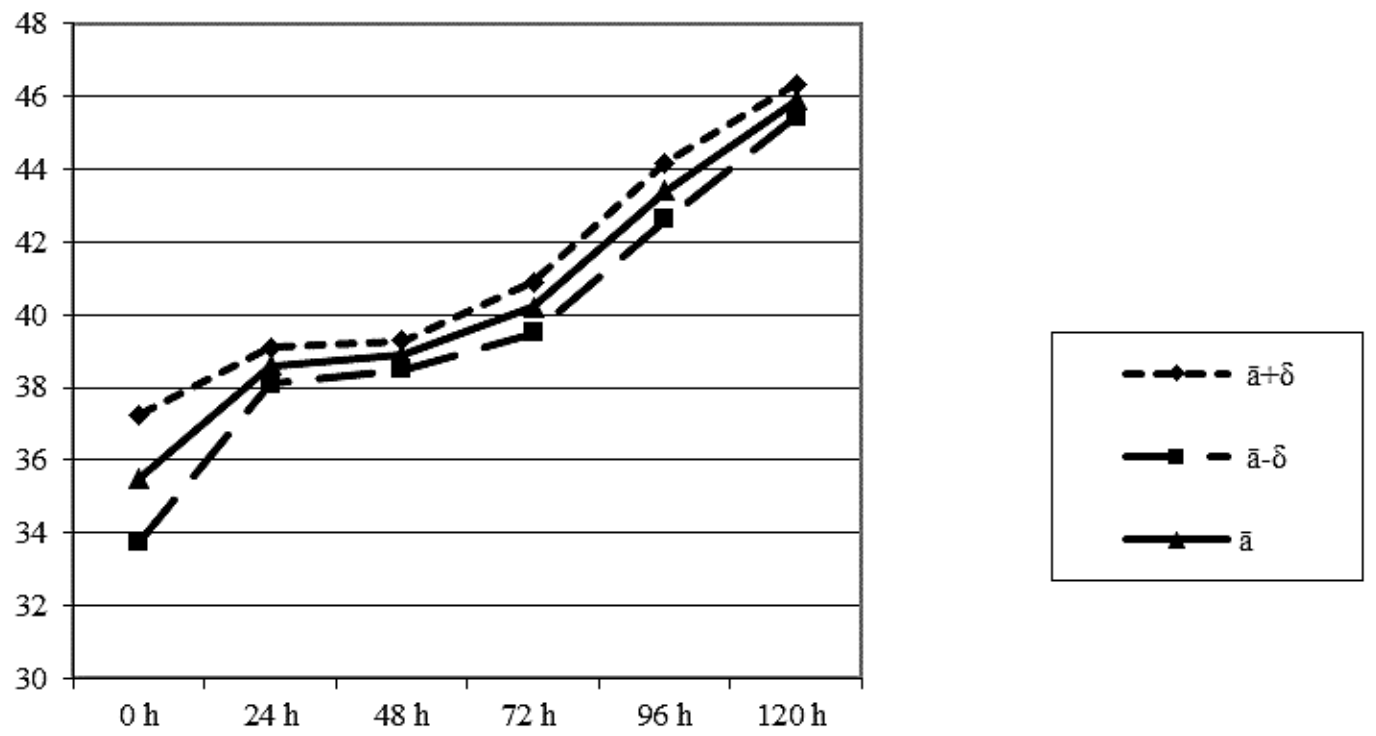

Fig. 2. Elasticity change of styrene-butadiene rubber after exposure

Source: own elaboration.

in soybean oil environment.

The rubber samples stored in soybean oil were subjected to ultraviolet radiation using a 20 watt UV lamp. Samples were stored for a period of 100 hours at $40^{\circ} \mathrm{C}$. The changes in hardness and elasticity of the rubber were controlled every 25 hours. The quality of the rubber surface was evaluated under the Neophot-2 light microscope.

Observed: increase of mean Shore's value by 1 unit, change of standard deviation ò -1 for samples stored in soybean oil to 2.5 for UV samples (after 75 hours), changes of elasticity compared to samples stored in oil and slight increase standard deviation after UV exposure.

Because of the macroscopic nature of the research by Shore's and Schoba's methods, it is possible to miss out information about microscopic phenomena.

The microstructural observation study made it possible to conclude that there are significant differences in the structure of the rubber surface before and after UV exposure (Fig. 3, 4).

The macroscopic inequalities shown in Figure 4 indicate the significant effect of fatty acids accelerating the development of operational damages. 


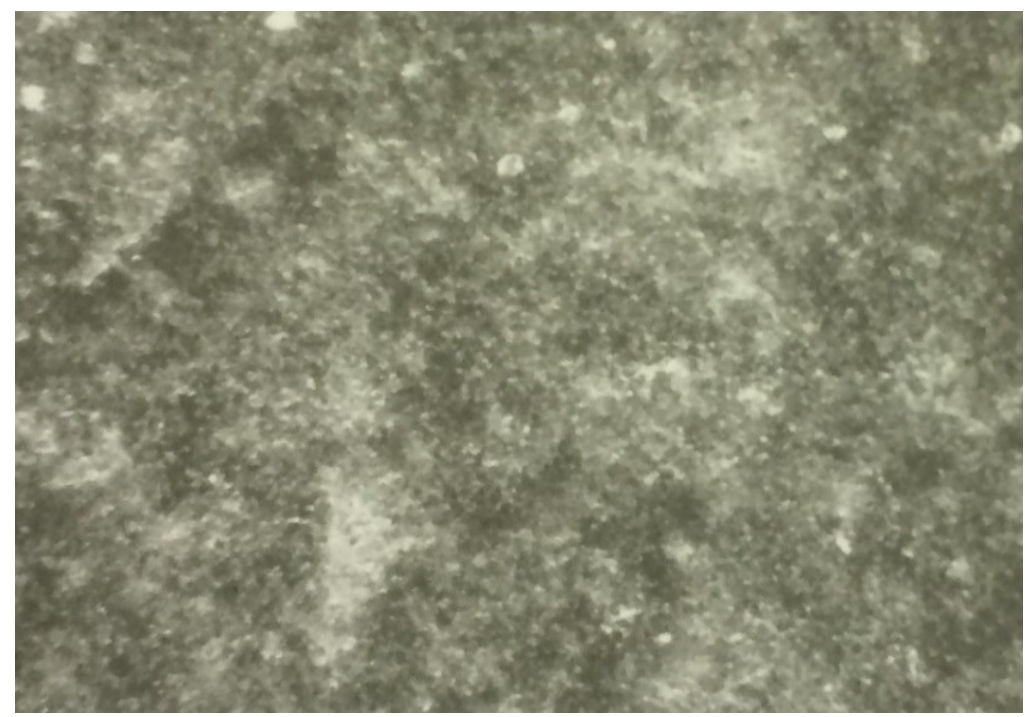

Fig. 3. Microstructure of conveyor belt rubber surface. Exposure in soybean oil for $\mathbf{5 0}$ hours.

Source: own elaboration.

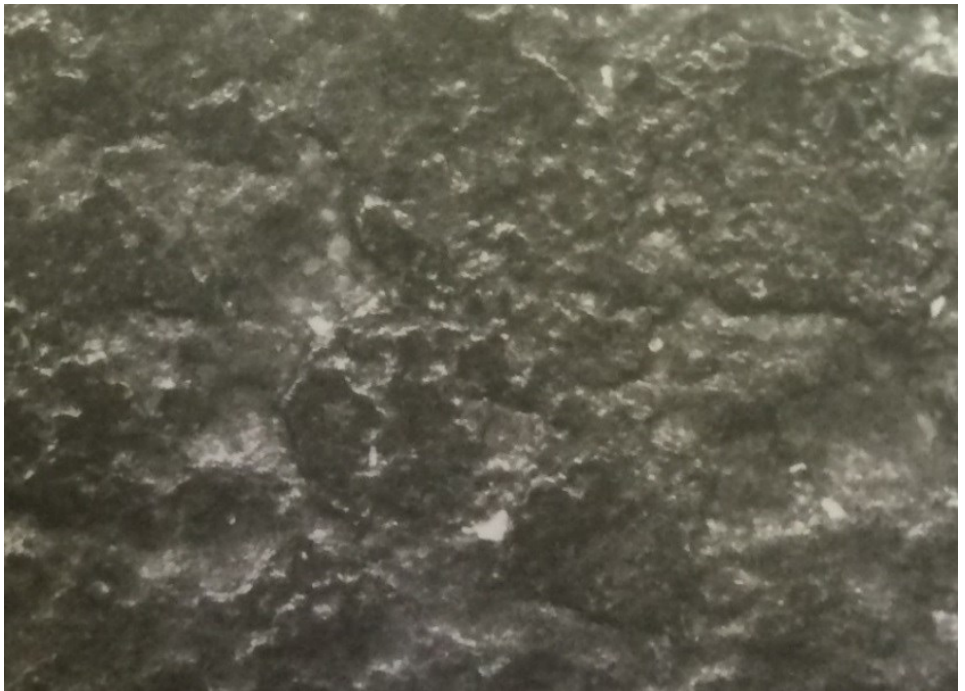

Fig. 4. Microstructure of rubber conveyor belt surface.

Source: own elaboration.

Exposure in soybean oil for $\mathbf{5 0}$ hours and UV for $\mathbf{1 0 0}$ hours.

\section{CONCLUSION}

As it has been shown in the presented studies, the rubber hardness decreased in the Shore's test once the elasticity of the material in the Schoba's test is increased.

The accelerating factor for the destruction of the belt coating was the microscopic heterogeneity created on its surface by the action of the fatty acid esters contained in the soybean seed cake in combination with the strong mass impact of the cargo striking the tape during the cargo handling causing the erosion of the belt.

There is a high risk that wear products of rubber conveying equipment may get into the cargo as contaminants that are useless impurities.

This situation may cause a decrease in the quality of the feed ingredient, is soybean meal, by a loss on value in use. Therefore, taking into account the risk of cargo contamination, the overhead conveyor belts should be made of oil resistant rubber.

The growing demand for this high protein feed increases its trade in the world. The research and literature of the subject show that, during cargo handling operations, conveyor belts are exposed to the degrading effect of fine and dusty fractions of soybean meal and grains of oil plants. 
Therefore, it is justified to use new solutions in the rubber structure and surface of conveyor belts. This situation makes it necessary to study on the quality in the direction of risks and transport safety this popular feedstock.

\section{REFERENCES}

Babicz-Zielińska E., Przybyłowski P. (2000). Wartość biologiczna składników żywności. Chemia żywności - skład, przemiany i właściwości żywności, praca zbiorowa pod red. Z. E. Sikorskiego. WNT.

Chmiel J., Drzewieniecka B., Sokołowska A., Przybylak P. (2010). Problemy zużycia taśm przenośnikowych w transporcie nasion roślin oleistych. Maintenance problems, pp. 207214.

Chachułowa J. (1997). Pasze. Praca zbiorowa. SGGW.

Drzewieniecka B. (2004). Właściwości technologiczne śruty sojowej w procesie transportowym. Przegląd Zbożowo-Młynarski, 1.

Drzewieniecka B. (2010). Environment Protection in Transport Processes of Soybean Seed Cake. Scientific Journals Maritime University of Szczecin, 23, pp. 31-35.

Drzewieniecka B. (2010). Effect of transport and technological quality factors of soybean meal on sea transport safety. Scientific Journals Maritime University of Szczecin, 23, pp. 24-30.

Drzewieniecka B. (2013). Effect of soybean seed cake fractions for safety in maritime transport. Scientific Journals Maritime University of Szczecin, 34, pp. 35-39.

Drzewieniecka B. (2014). Changes of transport-technological quality factors of fine particle solid bulk cargoes. Logistyka, 6.

IMDG Code. (2015). International Maritime Dangerous Goods.

IMSBC Code. (2015). International Maritime Solid Bulk Cargoes Code.

Kibar H., Ozturk T. (2008). Physical and mechanical properties of soybean. Int. Agrophysics, 22, pp. 239- 244.

Leśmian-Kordas R., Pilawski T. (1990): Towary pochodzenia roślinnego i zwierzęcego w transporcie morskim. WSM.

Leśmian-Kordas R., Drzewieniecka B. (2002). Logistyka składowania komponentów paszowych i transportowych. Logistyka, 4.

Manuwa S.I., Odubanjo O.O. (2005). Physical properties of soybean (var TGX 1019-2EB) LAUTECH Journal of Engineering and Technology, Vol 3 (2): pp. 88-92.

Migdał W., Borowiec F., Pyś J.B., Koczanowski J., Barteczko J., Furgal K. (2001). Wpływ udziału pełnotłustej śruty sojowej, rzepakowej lub arachidowej $w$ mieszankach pełnodawkowych dla tuczników na profil kwasów tłuszczowych i poziom cholesterolu w mięśniach szynki, schabu. Rośliny Oleiste, 7.

Molenda M., Montross M.D., Horabik J., Rose I.J. (2002). Mechanical properties of corn and soybean meal. Transactions of the ASAE, 45, pp. 1929-1936.

PN-C-04238:1980. Guma. Oznaczanie twardości wg metody Shore'a.

PN-C-04255:1997. Guma. Oznaczanie elastyczności wulkanizatów przy odbiciu metodą Schoba.

Polat R., Atay U., Saglam C. (2006). Some physical and aerodynamic properties of soybean. Journal of Agronomy 5(1): pp. 74-78.

Raji A.O., Favier J.F. (2004). Model for the deformation in agricultural and food particulate materials under bulk compressive loading using discrete element method. II Compression of oilseeds, Journal of Food Engineering, 64, pp. 359-371.

Seth I. Manuwa. (2011), Properties of Soybean for Best Postharvest Options. Soybean Physiology and Biochemistry Edited by Prof. Hany El-Shemy. Publisher InTech, Published online 02, November.

Sikorski Z.E. (2000). Chemia żywności. Praca zbiorowa. WNT.

Tańska M., Rotkiewicz D., Ambrosewicz M. (2009). Technological value of selected Polish varieties of rapeseed. Polish Journal of Natural Science, Vol. 24(2):pp. 122-132, Y.

Tavakoli H., Rajabipour A., Mohtasebi S.S. (2009). Moisture-dependent some Engineering properties o Soybean grains. Agricultural Engineering International: the CIGR Ejournal. Manuscript 1110. Vol. XI.

Sturaro A.R., Rella G., Parvoli D., Ferrara L. Doretti. (2003). Chemical evidence and risks associated with soybean and rapeseed meal fermentation. Chemosphere. Elsevier. Vol. 52, Issue 7, August,pp. 1259-1262. 